\title{
The Green Souvenir Industry of Kerala - A Comprehensive Analysis
}

\author{
Robinet Jacob*, Mahadevan $\mathrm{P}^{\dagger}$ and Anita T A $\ddagger$
}

\section{Abstract:}

Handicrafts and souvenirs have a long and glorious tradition behind them. They represent the culture of the people and from a great heritage of art. Souvenirs are a manifestation of the creative impulse of people. The specialty of the handicraft is that it reflects the craftsmanship of each and every part of the country. Souvenirs always remind a traveller of a particular place that it was purchased from. Souvenir trade improves the local economy and even serves as a brand image or icon of the destination visited by tourists while providing easy visibility. Souvenirs also help in the word of mouth marketing of a destination. The souvenir trade worldwide is part of a rich handicraft tradition that evolved over the years. India has a diversity of souvenirs, and so does Kerala. The uniqueness of Kerala isits abundance of plant or natural fibre-based souvenirs. But, little research has been done on the process of production or the potential it provides in promoting tourism. This study is an attempt to look into the problems and prospects of plant or natural fibre based - 'green souvenirs' of Kerala and to offer suggestions for improving its market.

\footnotetext{
* Director, School of Tourism Studies, Mahatma Gandhi University, Kottayam, Kerala, India; robinetjacob@gmail.com

† Travel \& Tourism Consultant, Visitor Facilitation Centre, District Tourism Promotion Council, Kochi, Kerala, India; machtourism@gmail.com

‡ Faculty Member, School of Tourism Studies, Mahatma Gandhi University, Kottayam, Kerala, India, Anita17672@gmail.com
} 
Keywords: Green souvenirs, natural fibres, value added products, souvenir marketing

\section{Introduction}

Shopping is an indispensable part of any tourism activity. No tour is complete without some shopping experience in the destinations visited by the tourist. Shopping is one of the most favoured travel activities (Timothy and Butler, 1995; Yu and Littrell, 2005:1; Timothy, 2005) and has obviously supported tourism growth and revenue contribution (Littrell, Paige, and Song, 2004:348). Another study has shown that touristsare spentone-third of their expenditure in shopping (Littrell, 1994:3). In Malaysia, it was reported that RM5.13 billion of tourist receipts in 2002 came from shopping, representing 20.6 percent of the RM25.8 billion tourism receipts (Ministry of Tourism Malaysia, 2009). In 2007, shopping tourism receipts registered a staggering RM12.2 billion, representing over one-fourth of the RM46 billion in tourism receipts (Tourism Malaysia, 2008). The trend is also the same in countries like India where tourism represents the resurgence in local economies.

\section{Concept of Souvenirs}

Souvenir is regarded as anything that a traveler or tourist collect or purchase and takes back to his country as a memento of his or her visit to the destination. The word souvenir comes from a French word meaning 'to come back to me' (Smith and Reid, 1994). Souvenirs remind tourists of a special event or memory (Swanson, 1994) and also enhance the brand image of the destination. Souvenirs can range from highly expensive items to attractive ecofriendly and natural materials. The value of the souvenirs will be more if they are handmade by local artisans.

\section{Historical Perspective of Souvenirs}

Early records mention that ancient Egyptians, Romans, and other explorer-travelers brought mementos home from their journeys abroad. During the period of exploration and colonization, voyagers came back with large quantities of handicrafts and artworks (Horner, 1993; Stanley, 2000). During the seventeenth and 
eighteenth centuries, the participants bought miniature replicas of sites of the cities they visited (Evans, 1998; Mars \& Mars, 2000). Many museums during the period even displayed the souvenir collections of the elite travellers (Jolliffe and Smith, 2001). The Native American tribes in the United States were encouraged to produce local souvenirs for travellers during the last three centuries (McLerran, 2009; Nicks, 1999; Phillips, 1998). It is also believed that modern day souvenirs have its true origin in Christian pilgrimages, where pilgrim travellers used to collect relics associated with saints (Houlihan, 2000; Shackley, 2006; Teague, 2000; Tythacott, 2000).

\section{Role of souvenirs in Tourism}

Souvenir shopping is an important activity in tourism, and souvenir business is a very potential area in the tourism industry. The visitors would like to cherish the memories of their visits forever. It covers all forms of mementos that tourists acquire during their experience as tourists. All the famous tourist destinations showcase a wide range of souvenirs. Souvenirs may be articles of utility or merely symbolical representations of the arts, crafts, and products of particular communities and countries. Souvenirs can be anything, which varies from indigenous art and craft products, clothing with a native flavour, merchandise of utility, exotic food, and drinks, etc.

Swanson (2004:364) notes that souvenirs and tourism are somehow associated. Souvenirs have been an active component of tourists experience and contribute to the local economy in many tourism destination areas (Jansen - Verbeke, 1998).Tourists frequently purchase souvenirs either for themselves or as a gift to someone back at home. Among the souvenir items purchased by tourists are local craft, postcards, fine art, accessories, jewellery, T-shirt, toys (Swanson, 2004:364), antiques, food, wildlife and nature objects, leather goods (Swanson and Horridge, 2006:673) and other items. Handicrafts have received maximum attention as souvenirs. Pottery, woodcarvings and figurines, baskets, blankets, clothing, fabrics, leather goods, and jewellery are regarded as the major handicrafts. This is perhaps supported by a study in the USA that local handicraft is one of the favoured item purchased by tourists 
when shopping (traveller's notes, 1995 cited in Kim and Litrell, 1999:153).

\section{Major Indian Handicrafts and Souvenirs}

India is a treasure house of handicrafts, textiles, and artefacts sold in posh shopping arcades or colourful local markets in all major cities. Each state has something indifferent to offer and exclusive to its region which includes metal crafts, jewellery, handicrafts, textiles, stone crafts, paintings, etc. Handicrafts can be classified by the medium on which they are produced. History shows that the crafts of India enjoyed a coveted place among ancient traders including Romans and Arabs. Indian silk, textiles, gold and silver and other handicrafts were precious possessions of Western countries. After Independence, the Government set up the Handicrafts Board to revive dying crafts. All India Handicrafts Board, established by Central Government in 1952, helps thepromotion of handicrafts, its production, and marketing through organizing several fairs periodically at all places.

Taking into account the number of tourists visiting India every year, the returns from the business could be quite promising. Besides, the business could create immense job opportunities, especially for women. Each state can identify its most popular subjects and entrust the leading designers to bring out exquisite pieces of art in a cost-effective manner. The central and state governments should provide incentives to the people behind it. Souvenirs can play multiple roles in tourism promotion. They advertise the country as an attractive destination. The business could offer high job opportunities, income and above all publicity. Souvenirs play an important economic role in tourism and have developed into vast and varied industries providing employment opportunities to many. Tourism has provided a tremendous motivation for the preservation and revival of art traditions and crafts in many countries. The craft export of India has grown from 23 crores to over 9000 crores during the past fifty years (India Handicrafts Board, 2014). 


\section{Souvenirs of Kerala}

Kerala, famed as 'God's Own Country' is rich in its handicraft traditions and is renowned for its handlooms, gold ornaments, spices, etc. The handicrafts of Kerala are unique in style, perfect and elegant in form and design. Popular handicrafts of Kerala include Aranmula Kannadi, Nettur Petti, Payyannur Pavithram, Kasavu mundu (Kerala handlooms), traditional gold jewellery, nettipattom, bell metal work, elephant woodwork, model boats and urus, Kathakali masks, coconut shell handicrafts, sandalwood and sandalwood oil, spices and Kerala paintings.

Tourists visiting Kerala spend only less than 5\% of their expenditure for souvenir shopping. The Kerala Tourism Department has to support production and marketing of exclusive local Kerala souvenirs. Even, the state Department of Tourism initiated a project of identifying a hundred souvenirs across the state. It is also a known fact that only a few souvenirs have received much attention and promotion from a tourism point of view and have become quite famous. A majority of traditional souvenirs and their artisans are struggling today for their livelihood. Most of these souvenirs are localized to few destinations only.

Another feature of Kerala souvenirs is that the state has a rich tradition of natural fibre based souvenirs. Apart from coir and to an extent bamboo or cane-based products, little attention has been made on documentation, promotion, and marketing of other natural fibre based products. Hence this study is an attempt to document on major fibre based souvenirs and focus on enhancing their visibility in the tourism market.

\section{Objectives of the study}

This paper intends to understand the importance of natural fibre based souvenirs in the tourism industry of Kerala. The study identifies different kinds of souvenirs made from natural fibres and analyses the process of making of the souvenirs. Another major objective is to document the problems faced by craftsmen or artisans involved in souvenir production and to understand the marketing and sales process. 


\section{Approach and Methodology}

Major plant based souvenirs or green souvenirs made from natural fibers in Central Kerala were selected for the study. The primary data was collected through visiting one unit each of the products selected and directly conducting a personal interview with key persons or artisans associated with the unit. The process of production was documented in most cases.

\section{Natural fibre souvenirs of Kerala}

Kerala, rich in its biodiversity is known for its large number of crafts and souvenirs made from plants and natural fibres. These can be termed 'Green souvenirs' as they are all made of natural or biomaterials and are eco-friendly. Examples of these include coir products, vetiver, grass mats, hay art, screw pine products, water hyacinth products, banana fibre and cane souvenirs. A brief description of each of these materials included in this study is provided below.

\section{Coir products}

Coir products are made from coconut husk. It is an important traditional cottage industry in Kerala from early days. Coir products are renowned for their biodegradable composition and long life. A number of products are made from this fibre in Kerala, and notable ones include doormats, rugs, wall hangings, door pieces, bags, hammocks, ceiling floor furniture, beds, cushions, little show pieces, blinds, purses, bags, bangles, etc. Coir industry is scattered throughout the state, but the high concentration is seen along the banks of backwaters especially in Alappuzha and Kollam districts.

\section{Vetiver (RamachamVishari)}

Popularly called 'Khus Khus' or 'Ramacham' (Malayalam), vetiver (comes from Tamil) is an aromatic herb that has many uses. It is a natural coolant, and the hand fan (Ramacham vishari) has been in use in Kerala since ancient times. Perfume oil and essence extracted from vetiver and chappals made from it are other products used widely. Recently, the plant with its thick roots is extensively used in eco-restoration and embankment conservation in many tropical countries. 


\section{Grass mats (Pulpaya)}

This is one of the oldest hand-woven products of Kerala and was widely used to sit as well as sleep. Mention of grass mats is even found in the Atharva Veda. The mats are made from the tall grass variety 'Korappullu' (Cyperus scorymbosus) belonging to the Papyrus family.

\section{Hay art}

This unique craft of Kerala makes use of hay or straw. This craft has recently attained popularity and is used to adorn the interiors of home and office like wall paintings. Hay or straw is cut to different sizes and images are created on cloth or canvas. The theme for these 'Vaikkol chitrangal' (hay or straw pictures) include backwater scenery, evening sky, boat races, village fairs and festivals, huts and hamlets, hills and valleys and other scenes from Kerala.

\section{Screw pine souvenirs}

Screwpine is a natural product available in marshy places. It is commonly known as "Thazha". It has been used for a long time to make items like "Thazhapa"- a mat commonly used in the households and made by the womenfolk of the house. Screwpine is being recently used to to make souvenirs. Pandanus fibres are very absorbent and easy to dye. Jawahar Society is an NGO working towards employing about 200 womento run a unit in Thalayolaparambu, Kottayam. Similar works are being done in places like Thazhava, Kollam, Alappuzha. People are being brought together under various cooperative organisations in the rural areas for this cottage Industry. A variety of souvenirs is made from screw pine like mat, sandals, handbag, cushions, table mats, waste bin, tissue box, flower basket, folder, fruit tray, laundry bin etc.

\section{Water Hyacinth products}

These are tender and perennial aquatic plants and multiply quickly and choke water bodies like lakes, rivers, and canals. Scientifically called Eichhornia, it is native to South America. Though it is a problem in Kerala's water bodies, recently many products are 
being made from it including paper, yarn and ropes, baskets, fertilizers, animal fodder and fish feed.

\section{Banana Fibre}

Banana is a popular tropical fruit and has a very auspicious value in Indian culture. The seedless fruits can be eaten raw or ripe, and its flowers are also edible. Even the leaves of banana are used as plate for eating in South India. Its fibres are used in the making of handbags, baskets, mats, sarees and other materials.

\section{Cane}

Cane is obtained from bamboo and grows wildly in tropical forests. Belonging to Poaceae family, they have flexible and woody stalks. Cane is used for a variety of purposes. A number of products including flower baskets, hanging baskets, bamboo curtains etc. are made from cane.

\section{Major findings of the study}

The major findings of the study with relation to the problems faced by green souvenirs are:

- There is a scarcity in the availability of raw materials

- Most of the products are climate dependent and therefore seasonal, and have short life span

- Today, traditional hand made products are rare; machines are used in the process of making green souvenirs

- Chemicals are used in dyeing and several other processes

- Unskilled workers undertake most of the production process

- Workers are paid on a piece rate system

- The production is based on demand

- Exhibitions are the primary conduit for marketing of the souvenirs

- There is no combined strategy towards linking the products with the tourism industry 
- Little financial support exists from the Government and the Department of Tourism

\section{Suggestions for improving marketing of 'green souvenirs.'}

The study identified the challenges faced by the 'green souvenir' industry of Kerala and the constraints and limitations of marketing the product. The authors make the following recommendations to improve the existing status quo of this industry:

- Raw materials should be made available locally for the industry

- Organic and natural dyes should be used in the production process

- Biofertilizers can be used for growing the raw materials

- Handmade production should be encouraged for retaining the authenticity and increasing value

- Proper technical training should be providedto enhance trained manpower for the industry. Central Government institutions must provide increased funding for training and development of handicraft industry.

- More value added products that align better with marketing of the tourism industry should be produced

- Greater awareness of the value that these raw materials provide to the industry and therefore the economy of the region should be disseminated among the local population

- The products should find more distribution channels including direct linkage with tourism industry

- The souvenir craftsmen can partner with tourism service providers like Responsible Tourism initiatives of Government of Kerala for improved marketing of their products.

- Create several cooperative societies representing various handicrafts and combine them into a marketing channel to improve visibility. 


\section{Conclusion}

Kerala has a rich tradition of natural fibre based souvenirs. So far little attention has been paid to documentation, promotion, and marketing of these natural products. This study is an attempt to document major fibre based souvenirs and enhance their visibility in the tourism market. Another concern is to keep the process as authentic as possible so that it doesn't get mechanized and the traditional process is not lost forever. Also, one drawback of this natural fiber based souvenir is durability. If this can be addressed effectively without the use of preservatives or chemicals, these souvenirs can go a long way in promoting Kerala Tourism to a great extent. Concerted efforts should be made to bring awareness about the importance of the souvenir market to all stakeholders and provide them the necessary support to promote this trade.

\section{References}

Anderson, L. F., \& Littrell, M. A. (1995). Souvenir-purchase behavior of women tourists. Annals of Tourism Research,22(2), 328-348. doi:10.1016/0160-7383(94)00080-8

Cohen, E. (1995). Touristic craft ribbon development in Thailand. Tourism Management,16(3), 225-235. doi:10.1016/02615177(95)00007-b

Jacob, R., Joseph, S., \& Philip, A. (2007). Indian tourism products. Delhi: Abhijeet Publications.

Kim, S. (1997). International Tourists' Souvenir Purchasing Behaviour, Ames, Iowa; Iowa State University.

Kim, S., \& Littrell, M. A. (1999). Predicting Souvenir Purchase Intentions. Journal of Travel Research,38(2), 153-162. doi:10.1177/004728759903800208

Kim, S., \& Littrell, M. A. (2001). Souvenir buying intentions for self versus others. Annals of Tourism Research,28(3), 638-657. doi:10.1016/s0160-7383(00)00064-5

Littrell, M. A., Anderson, L. F., \& Brown, P. J. (1993). What makes a craft souvenir authentic? Annals of Tourism Research,20(1), 197215. doi:10.1016/0160-7383(93)90118-m 
Littrell, M. A., Baizerman, S., Kean, R., Gahring, S., Niemeyer, S., Reilly, R., \& Stout, J. (1994). Souvenirs and Tourism Styles. Journal of Travel Research,33(1), 3-11. doi:10.1177/004728759403300101

Swanson, K. K., \& Horridge, P. E. (2004). A Structural Model for Souvenir Consumption, Travel Activities, and Tourist Demographics. Journal of Travel Research J Travel Res,42(4), 372380. doi:10.1177/0047287504263031

Swanson, K. K., \& Horridge, P. E. (2006). Travel motivations as souvenir purchase indicators. Tourism Management,27(4), 671683. doi:10.1016/j.tourman.2005.03.001 